of Nations itself. The activities of the Advisory Committee on League of Nations Teaching continue to be reflected in the volume, which as in previous years gives publicity to those League activities likely to be of particular interest to educationists. The admirable series of articles in the present volume, particularly those on the role of intellectual co-operation in contemporary life and on the use of modern means of spreading information in the cause of peace, give it, however, strong claims on the attention of all who are studying or seeking to promote international co-operation and understanding. Moreover, the articles on the League of Nations at work, which covers the problem of raw materials and the League of Nations; the reform of the League; the League of Nations and International Hygiene; and Changing Aspects of Child Welfare, and on the International Labour Organisation, dealing particularly with the raising of the minimum age of admission to employment, represent concise and balanced surveys of the present situation of these problems which should be of real service to the speaker or general student. The reprints of broadcasts such as that on nutrition and the Singapore Health Bureau, of Sir Malcolm Delevigne on opium and drugs, and of Prof. Gilbert Murray on intellectual co-operation, provide other material of the same type.

\section{Copper and Brass Welding in Germany}

Is 1936, the Deutches Kupfer Institut of Berlin published a valuable pamphlet describing carefully the best methods of welding copper and brass. The Copper Development Association of London has now translated this into English. It is pointed out that there are certain differences between German and British welding practice, mainly associated with the general employment in Great Britain of deoxidized copper. But knowing the high standard of excellence which has been achieved in Germany, there is much of it which will be of value to British readers. The hand-made copper and bronze domestic vessels shown in the Berlin State Museum and dating back thousands of years prove that soldering and riveting were in common practice from very early times. In course of time, the necessity arose for a new and improved jointing technique which would produce smooth and strong joints and yet avoid the expense of riveting. This demand is universally met to-day by the adoption of welding. The development of copper welding has been much slower than that of steel, but the difficulties in the way have now been largely overcome, and welded copper appliances of the highest quality are now produced. Deoxidized coppers, which are extensively used in Great Britain, are not discussed in this pamphlet. The thermal conductivity of copper is about six times that of steel. Molten copper readily dissolves other metals and forms the basis of several important alloys. With zinc it produces brass and with tin bronze. The thermal conductivity of brass is two or three times that of steel, and only about one third that of copper. This feature is a decided advantage in welding. For this reason, brass requires a smaller flame for welding than copper. Although gas welding is the one most commonly used, new electrical methods are in process of development which will probably enable arc welding to be profitably employed.

\section{The Clock of the Future}

AT the British Horological Institute in Iondon, on January 12, an interesting discussion was held on the respective merits of spring-wound and electric clocks. Mr. D. W. Barrett, of Smith's English Clocks, Ltd., began by pointing out that his firm has large investments in spring-driven clocks and its business was founded on them. He claimed to be impartial and he would not have taken up the electric type had he not been assured of its future. A spring-wound clock cannot be relied upon to give accurate time. It needs regular winding and its parts are delicate. The electric clock needs no attention and is robust. It is true that it stops when the current fails, but on the average this only happens once a year. There are areas where no break has been recorded for three years. In the United States, 66 per cent of the sales were of electric clocks. In Great Britain about 33 per cent of the money spent on clocks last year was for electric clocks of the synchronous type. When it is remembered that the spring-wound clock has been in existence for three hundred years whilst the electric clock has only been on the market for some seven years it will be seen that the latter is the more popular. There are about 45 million clocks in use in Great Britain, the bulk of them being spring-driven. There can be little doubt but that the electric clock will be the clock of the future. It is practically immune from the effects of heat and damp.

\section{The Soviet Institute of Physical Problems}

PART 3 of the Physics Bulletin of the Soviet Academy of Sciences for 1937 contains Dr. P. Kapitza's address to the Academy last March, which he devoted to an account of the new Institute founded by decree of December 1934. The building, which has taken a year longer to complete than was anticipated, is, although only 80 metres from Moscow tram lines, surrounded by gardens in which other institutes of the Academy are to be built. It nearly surrounds a quadrangle $40 \mathrm{~m} . \times 25 \mathrm{~m}$., with outer walls $63 \mathrm{~m}$. $\times 50 \mathrm{~m}$., the long side nearly north and south. The south-eastern corner is not built on, and gives access to the quadrangle. The main laboratories are on the ground floor, and provision for very sensitive apparatus is made in the basement. A first floor over the easterm block is occupied by the administra. tive department. By introducing a simplified system of book-keeping, Dr. Kapitza has reduced the five accountants originally thought necessary to one. The apparatus taken from Cambridge has been installed and is described. It includes the Metropolitan-Vickers altermator and the coil through which it is shortcircuited to produce for $1 / 100$ sec. an intense magnetic field, the hydrogen liquefier producing 7 litres per hour and the helium liquefier which first cools the gas to $65^{\circ}$ absolute by means of liquid nitrogen, then 
to $10^{\circ}$ abs. by adiabatic expansion and finally liquefies it by the Joule-Kelvin cooling. A new machine on this plan is now being constructed to work with a double cycle and deliver 6-8 litres per hour.

\section{History of American Agricultural Research}

A "History of Agricultural Experimentation in the United States, 1607-1925", by A. C. True, has just been issued as Miscellaneous Publication No. 25l by the United States Department of Agriculture, Washington, D.C. This is the third official monograph in a series intended to give a comprehensive summary of the history of agricultural education, extension and research in the United States, the two previously issued having dealt with agricultural instruction in schools and colleges, and the history of agricultural extension work respectively. The present volume naturally begins with the work of private individuals including some biographical information, and shows how they and organizations such as the geological surveys and the Patent Office, themselves little con cerned with research, laid the foundations of public agencies for agricultural investigation. It will be noted with interest that the first governmentel movement to help agriculture was made when George Washington was president, while Federal State aid for the agricultural experiment stations, founded by pioneers all over the country, was secured by Hatch in 1887 by the passage of an Act bearing his name. The rapid development of research from this period up to 1913, the effects of the Great War and the agricultural depression of 1921-25 are then described in detail. A bibliography of more than three hundred references is appended. These are limited to sources of information used in the text and to bibliographical sketches of some of the leading figures in the earlier periods of agricultural development in the United States.

\section{Marine Fauna of the Isle of Man}

The publication of a new local fauna list is always an event of some interest, and it is of importance when it concerns such historic ground as that of the sea around the Isle of Man ("Marine Fauna of the Isle of Man". Compiled by Dr. Hilary B. Moore. Editor : Dr. R. J. Daniel, assisted by J. R. Bruce and Dr. M. W. Parke. University Press of Liverpool, 1937. 2s.). This up-to-date list of the marine animals found in that region is therefore to be warmly welcomed. Future visitors to the Biological Station at Port Erin will be grateful to Dr. Moore, a former member of its staff, for his work of compilation. $\mathrm{He}$ has been wise in following the same general plan as that of the well-known "Plymouth Marine Fauna", giving after each recorded name a reference to a good description, adding notes on the ecology, and breeding dates when known. There are three charts and a general introduction describing the most accessible and typical grounds. Dr. Moore and the editors have done their work well, while the printers have succeeded in producing well-balanced and attractive pages. As a work of reference, this list will be much used; to those studying the marine ecology of our islands it will be invaluable. We should like to suggest that in future editions a note be included as to the origin of the ancient drawing of a viking ship which so attractively adorns the cover.

\section{The Film in Education}

IN "The Film in Relation to the School Curriculum" (pp. 70 ; price 1s.) the Central Information Bureau for Educational Films, Ltd., has provided a useful reprint of a series of articles which appeared in Film Progress from July 1936 until July 1937. It deals with the teaching of geography, natural history, natural science and physical training. The advice given is in close accord with the Board of Education's "Suggestions for the Consideration of Teachers", "Suggestions on Health Education" and "Science in Senior Schools", long excerpts from which are reproduced. A report to the Manchester Education Committee on experimental film-teaching is quoted in support of the assertion that children are stimulated by this means to further effort in geography and nature-study. It is claimed that their interest and mental activity are so aroused as to lead them to seek out knowledge for themselves, their powers of observation and memory are increased and, in the case of geography lessons, the film tends to eliminate anti-foreign bias. Although some teachers prefer still pictures, it seems obvious that these cannot compete with such films as "The Life-Cycle of a Plant", "The Blowfly", "The Amœba" and physical training films.

\section{Battersea Polytechnic}

IN its recently published report for 1936-37 the Battersea Polytechnic directs attention to the increased volume and high standard of its research work. In the past, this has been pursued mainly in chemistry, physics and mathematics, but new facilities have made possible extended programmes in the Mechanical and Civil Engineering Department. In the Electrical Engineering Department, the demand for accommodation for research work could not be fully met. For researches in chemistry two Ph.D. and one M.Sc. were awarded by the University of London. Fifty-four other degrees of the University of London and thirty-four National Certificates in Engineering were obtained in addition to many other examination successes. An enumeration of positions obtained by Polytechnic students during the past thirteen years includes 1,218 domestic science inspectors, teachers, organizers and practitioners, 413 engineers, 413 health visitors, sanitary inspectors, nurses, etc., 233 chemists and 97 art practitioners. The general recognition of the enormous national importance of sound teaching in domestic science may be expected to lead to increased activity in this department of the Polytechnic.

\section{The Plant Hormone Committee}

As the outcome of a meeting held at the Royal Botanic Gardens, Kew, on November 6 (see Nature, 141,88 ; 1938), a Committee, to be known as "The 